Terry Rey, The Priest and the Prophetess: Abbé Ouvière, Romaine Rivière, and the Revolutionary Atlantic World. New York: Oxford University Press, 2017. 344 pp. (Cloth us $\$ 74.00$ )

This labor of love, a twin biography of two figures operating at the margins of the Haitian Revolution, decenters most of the traditional historiography of that world event. While previous histories of the Revolution have generally explored it in the secular terms of class, politics, nation-building, and human rights, Terry Rey probes its religiosity: how African Vodou and, especially, Catholicism inspired its adherents.

The protagonists of The Priest and the Prophetess embody the cultural complexity in Saint-Domingue's colonial crucible. Romaine-La-Prophétesse, a free black coffee planter, attracted thousands of insurgent followers convinced by his visionary revelations from the Virgin Mary to conquer Léogâne and Jacmel. Félix Alexandre Pascalis Ouvière, an ally of both André Rigaud and Robespierre, was a defrocked, married priest from Aix-en-Provence who fled his enemies in France to imagined safety in Saint-Domingue in 179o. The two men concluded a treaty in Le Trou Coffy in December 1791 and the priest returned to Paris, where Ouvière ran afoul of the Revolution and fled via England and Jamaica to Philadelphia. There he put his youthful scientific training to work, practicing medicine and publishing numerous tracts in the burgeoning American republic. Rey is the first historian to identify the abbé Ouvière as the American scientist and deist, Félix Pascalis, his American nom de plume.

The book alternates between chapters that move the action forward and discursive asides on the religious and cultural contexts. Chapters 1, 4, and 6 narrate the rise of Romaine's 1791 Trou Coffy insurgency, his followers' conquests of Léogâne and Jacmel, the encounter of Romaine and Ouvière in treaty negotiations, and the French suppression of Romaine's insurgency. Chapters 2-3 backtrack chronologically to explore the two men's origins and influences. Chapter 5 considers the alliances of Catholic priests with slaves and free people of color in Saint-Domingue throughout the eighteenth century. Chapters 7-8 follow Ouvière to Paris and then to Philadelphia. Chapter 9 is devoted to exploring how Romaine-la-Prophétesse was represented in subsequent histories, fiction, and popular memory.

The best chapters were those revealing the biographical trajectories of the two protagonists. Rey's nuanced reconstruction of Romaine's life from notarial records, parish registers, and eyewitness accounts strips away later historians' careless or ideologically suspect mistakes and makes for a lively, engaging, thought-provoking read. Likewise, the charismatic abbé Ouvière's repeated

(C) SUE PEABODY, 2018 | DOI:10.1163/22134360-09203045

This is an open access article distributed under the terms of the prevailing CC-BY-NC license 
scraps with orthodoxy, along with his similarly messianic visions of grandeur, capture his youthful audacity. Ouvière's transformation into the American doctor and scientist, Félix Pascalis, further illustrates his opportunism and Zeliglike omnipresence in the Atlantic Age of Revolution.

Rey's deepest interests are in the religious practices and beliefs of Romaine and his followers. He explores the African forms of Catholicism already present in Saint-Domingue and Santo Domingo, the role and forms of Vodou, and the religious and monarchical inspirations of the free colored and formerly enslaved insurgents. Carefully parsing claims by previous historians and anthropologists of colonial Saint-Domingue and the Haitian Revolution-from Thomas Madiou and Beaubrun Ardouin, through C.L.R.James, Jean Price-Mars, Jean Fouchard, and Gabriel Debien, to Laurent Dubois and Jeremy Popkin, among many others-Rey, like John Thornton, emphasizes the deep roots of African Catholicism in Congo over the emerging forms of Vodou during the revolutionary juncture that propelled Romaine into his brief moment of fame and power. Rey's appreciation of James Sweet's work is palpable in the chapters devoted to the prophetess. By Rey's account, Romaine's marginalization in history and popular culture is due to Haiti's historiographical "class war," wherein French-educated elite authors have marginalized the African-inspired leadership and participation as "simply too black, too un-French, and too uncivilized" (p. 206).

Unfortunately, the biographical mode can tempt a writer into romantic heroism, and many historians will feel that Rey steps over the line. He presumes abolitionism on the part of his heroes without exploring these ideas with the same nuance as in his detailed assessments of Catholic and Vodou theologies and rites. Both Romaine and Ouvière are described as "abolitionists" (p. 138) with limited supporting evidence. As in most histories of the Haitian Revolution, women, such as Romaine's enslaved fiancée, Marie Roze Adam, and Ouvière's second wife, the American Elizabeth Harris McClintock, flit by as pale shadows against the backdrop scenery of battles and men's careers. Their motives, economic resources, and appeal to their husbands are not deeply investigated.

By illumining the Haitian Revolution through Catholic people, ritual, and ideology, Rey has restored a key perspective generally missing from most historical interpretations of this period. The Priest and the Prophetess is an engaging, fresh, and thought-provoking read.

\section{Sue Peabody}

Department of History, Washington State University, Vancouver speabody@wsu.edu 